\title{
Iluminação teatral em contextos escolares: uma proposta didática
} Theatrical lighting in school contexts: a didactic proposal

\author{
Laura Maria de Figueiredo ${ }^{1}$
}




\section{Resumo}

Este artigo aborda o potencial da iluminação artificial para práticas de ensino de teatro em contextos escolares, a partir dos conceitos relacionados às perspectivas da pedagogia do espectador de Flávio Desgranges e reflexões de Walter Benjamin sobre jogo infantil e brinquedo. Apresento um dispositivo didático para subsidiar o aprendizado inicial das relações entre luzes e cores por meio de uma maquete que simula o ilusionismo do palco de boca de cena, para propiciar leituras possíveis surgidas a partir da presença da luz como recurso cênico expressivo. Esse artefato foi desenvolvido para aulas de teatro para crianças e jovens em contextos escolares e inspirado nas ideias de Benjamin, reconhecido teórico do Teatro Épico de Brecht e pensador da educação infantil. A maquete propõe o espírito de brinquedo e brincar com luz, espaço e cor e possibilita a aproximação entre alguns tópicos básicos sobre iluminação teatral, corpos, objetos e espaço cênico que fazem parte dos conhecimentos que propiciam 0 desenvolvimento do espectador épico, seguindo as proposições de Desgranges.

Palavras-chaves: Iluminação teatral; ensino de teatro; pedagogia do espectador

\section{Abstract}

This article addresses the potential of artificial lighting for theater teaching practices in school contexts, from concepts related to the perspectives of Flávio Desgranges' viewer pedagogy and Walter Benjamin's reflections on children's play and toys. I present a didactic device to support the initial learnings of the relations between lights and colors through a model that simulates the illusion of the proscenium stage, to provide possible readings arising from the presence of light as an expressive scenic resource. This artifact was developed for theater classes for children and young people in school contexts and inspired by the ideas of Benjamin, a renowned theorist in Brecht's Epic Theater and thinker on early childhood education. The model proposes the toy spirit, playing with light, space and color and allows the approximation between some basic main points about theatrical lighting, bodies, objects and scenic space that are part of the knowledge that propitiates the development of the epic spectator, following the propositions of Desgranges.

Keywords: Theatrical lighting; theater teaching; viewer's pedagogy

\footnotetext{
1 Professora Assistente no Curso de Licenciatura em Teatro - Universidade Federal do Rio Grande do Norte (UFRN). Doutoranda no Programa de Pós-Graduação em Educação da UFRN. Diretora Teatral e lluminadora Cênica - ॥laufigueiredo@gmail.com
} 
A pedagogia do teatro como campo epistêmico abrange as diversas possibilidades de ações educacionais que se instrumentalizam para transformar conhecimentos sobre teatro em metodologias de oficinas, cursos formais ou cursos livres para troca e transmissão de saberes relacionados ao universo teatral. Trabalhando em vários níveis de complexidades e contextos de realização, seja nos cursos profissionalizantes para formação de artistas (bacharelados e cursos técnicos), seja para formação de professores nas licenciaturas em teatro, seja no universo multifuncional das oficinas de treinamentos em técnicas cênicas, esse campo é composto por inúmeras práticas técnicas e poéticas e suas correspondentes teorias extraídas dessas artes do palco, ou agregadas à elas para subsidiar olhares sobre tais processos inseridos em diversos contextos, entre eles o da escola formal e os processos de ensino e aprendizagem de teatro para crianças e jovens do ensino fundamental.

Historicamente a vertente do ensino de teatro voltado aos saberes e práticas relacionados aos temas de atuação e dramaturgia predominaram durante grande parte do século XX, e nesse viés as práticas pedagógicas derivadas de jogos de atuação, criação de personagens e produção de textos tornou-se práxis corrente. Aos poucos na passagem para o século XXI esse panorama foi se alterando em vista do protagonismo que a teatralidade assumiu como fonte de novos fundamentos para as práticas cênicas. A/o espectadora/dor do teatro moderno necessita de um olhar treinado para decodificação das manifestações formais e estéticas de diversos elementos visuais da cena, entre elas o desenho de luz.

Levando em consideração a importância para o teatro moderno das proposições teóricas e metodológicas de Bertolt Brecht (1898-1956) contidas na caudalosa produção prática e conceitual sobre o Teatro Épico, Flávio Desgranges (2015) propõe o conceito de espectador épico a partir de interlocuções com as proposições de Walter Benjamin (1985), com sua filosofia da história e da crítica literária nos ensaios instigantes sobre o alcance do conceito do épico em Brecht. Agregando Mickail Backhtin de quem extrai o conceito de contemplação e dialogismo participativo dos produtos da arte, Desgranges desenvolve instrumentos analíticos a partir destes autores para pensar sobre ações de formação de espectadores teatrais movidos por atitudes e olhares épicos em direção à cena. Partindo do princípio "todo o palco épico gesticula", no conceito brechtiano do gestus cujo desenho se lê, se interpreta e se debate a partir do topos da plateia e por meio dessas mediações na relação cena/público pode-se instaurar ações formadoras de espectadores instrumentalizados para apreciar criticamente as peças teatrais.

No palco épico proposto pela encenação brechtiana as inovações tecnológicas do período influenciaram o uso de projeções cinematográficas, palcos motorizados e outros elementos cenográficos que apoiavam as intencionalidades de contextualização histórica, comentários e rápidas transformações de situações espaço-temporais das narrativas em jogo na peça.

A partir dessas proposições pode-se pensar dentro da pedagogia do teatro como elaborar metodologias de formação de plateias objetivando instrumentalizar aprendizes e estudantes de teatro nas diversas formas de observação e decodificação dos elementos da iluminação cênica, investigando como estes operam seus trabalhos e 
tarefas sobre a cena, para a construção do espetáculo épico ou não. Em vista desse objetivo este processo de trabalho traz uma proposta pedagógica para construção de um lugar de leitura para algumas das tarefas da luz sobre um palco a partir do espectador épico tal como é caracterizado por Desgranges (2015), no sentido daquele que vê com distância e que articula criticamente o que vê por conhecer as técnicas como aquilo foi produzido. Trata-se de uma recepção ao espetáculo emancipada do simples papel de receptor. A/o espectadora/dor deve pensar e refletir sobre o que vê e o que experimenta na relação palco/plateia, a partir de conhecimentos que se consolidam com a prática da apreciação crítica. "Assumindo a função que lhe cabe no evento, (co-) autor da obra de arte, o espectador teatral pode ser definido como produtor de conhecimentos, já que o ato de compreender demanda elaboração" (Desgranges, 2015 p.131).

No atual cenário das produções cênicas podemos verificar que a iluminação cênica possui potencial de ancorar algumas práticas voltadas para a formação de plateias conscientes dos signos operados pelas luzes, em vários tipos de espetáculos realizados nos espaços convencionais de apresentações públicas. Seja qual for o gênero de teatro examinado pelo espectador épico: drama, comédia, musical, tragédia, ópera, performance e outros, ele ou ela poderá aprimorar a sua experiência e suas capacidades de interação e produção de conhecimentos diversificados sobre espetáculos teatrais, a partir de conhecimentos sobre as formas de produção de sentidos operados pelas diversas tecnologias da cena, entre elas a iluminação. No teatro moderno ela se tornou uma fonte inesgotável de práticas e teorias articulando sua presença estruturadora de diversos elementos das encenações.

Esta proposta didática se insere na busca de desenvolver os potenciais educacionais na área das tecnologias da cena, e dentro dela a luz, com o propósito de difundir e democratizar conhecimentos para apreciação, de modo crítico, sobre o modus operandi da iluminação no mundo contemporâneo, e suas manifestações em nossa massificada sociedade dos eventos espetaculares. No universo do teatro esses conhecimentos embasam as composições visuais concretizadas pelas propriedades manipuláveis nos jogos entre espaço e iluminação cênica realizados em diversos contextos culturais e artísticos. Para além da magia e da beleza a iluminação cênica produz inúmeras possibilidades de estímulos à formação do espectador épico.

\section{Prática pedagógica - o espectador adentra à luz do palco}

Para propiciar uma modalidade de educação estética para as manifestações da iluminação cênica elaboramos um dispositivo didático para que estudantes em dois contextos, curso de teatro e na escola pública pudessem manipular materialmente algumas lições básicas de luz relativa a cores e caixa cênica de tradição italiana. No nosso mundo da hiperatividade da visão, esse equipamento de ensino de iluminação para o teatro foi pensado para criar um topos diferenciado para processos de ensino-aprendizagem sobre luz, por meio de uma maquete como um teatro de brinquedo?

2 A maquete foi construída com a colaboração de Camila Tiago, mestre em Artes Cênicas pelo PPGARc da UFRN e diretora de iluminação no curso de Teatro do Instituto de Artes da UFU; e Juciê Borges, monitor na disciplina lluminação Cênica no Cenotec - Laboratório de Estudos Cenográficos e Tecnologias da Cena 
Introduzir esses elementos de construção cênicos para crianças e jovens a partir da experiência de iluminar um mini palco, colocando-as/os em contato com esta linguagem por meio de uma caixa, tal como Walter Benjamin (1984) descreve o encanto da caixa de brinquedo, como o local que captura a atenção da criança, e onde o exercício da contemplação possa fazer o mundo inteiro desaparecer, por meio da concentração absorta e repleta de visões de personagens ficcionais iluminados nesse pequeno palco e criado com o espírito lúdico e infantil que mora no ser humano.

Nessa maquete reproduzindo as instalações básicas deste tipo de palco e sua estrutura tecnológica de suporte da iluminação cênica e cenários, onde foram instaladas lâmpadas e outros dispositivos cênicos para reproduzir as condições de visibilidade de tal morfologia arquitetônica, para o público em geral. Além disso, foram acopladas instalações elétricas para lâmpadas e um mini painel operacional para a realização de experimentos interativos entre os estudantes e/ou curiosos com a maquete.

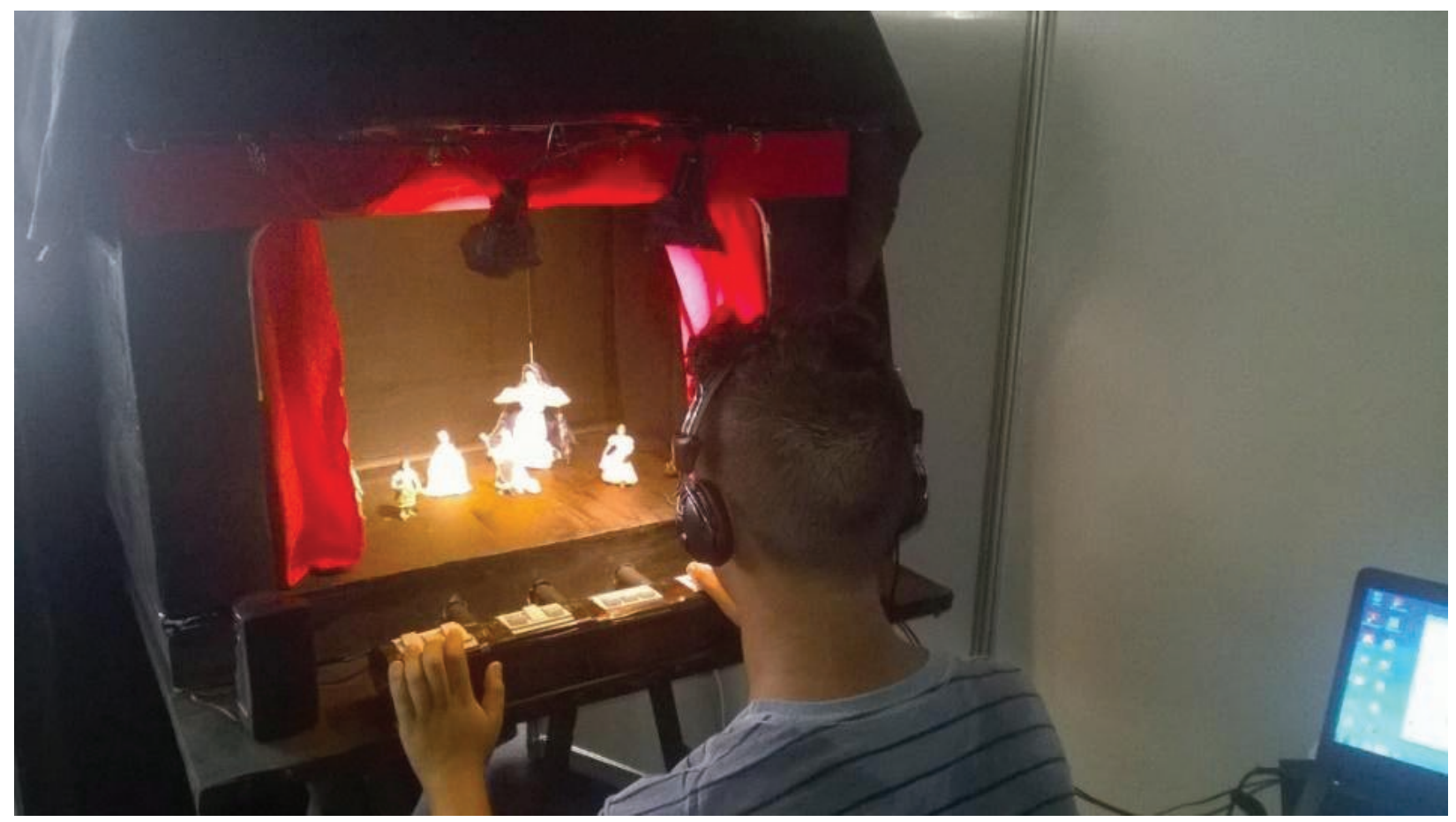

Figura 1 - 0 palco como caixa de brinquedo. Foto da maquete apresentada na Cientec/UFRN 2017.

Foto: Juciê Borges

Num dos formatos possíveis de interação a/o jogador ouve um áudio de instruções operacionais e executa os comandos de voz através de um fone de ouvido, que Ihe possibilita realizar/operar alguns efeitos de luz cênica, contendo lições básicas de estética de iluminação cênica sobre cores e suas interações na superfície de um palco iluminado. (Figura 1).

Por meio desse instante suspenso no fluxo do tempo em que manuseia botões acendendo e apagando luzes de forma instintiva e/ou conduzida pela fone de ouvido, a/o jogador experimenta diversas composições coloridas para as figuras/personagens colocadas nesse mini palco de brinquedo, geralmente pequenos bonecos

no Departamento de Artes - CCHLA UFRN. 
para representar corpos dos artistas, bibelôs e outros dispositivos cênicos como cenários e adereços.

A caixa de boca de cena de brinquedo é um dispositivo didático com potencial de estimular a imaginação e a curiosidade da criança, e da/do jovem e/ou adulto que se aproxima do modo lúdico proposto pela maquete, cujo manuseio proporciona aprendizagem de lições sobre iluminação artística (figura 2). Nesta maquete/ caixa de brinquedo separamos três elementos da luz cênica a serem investigados por meio de uma apreciação visual: espacialidade dos corpos/objetos, cores básicas e composições construídas com atmosferas luminosas.

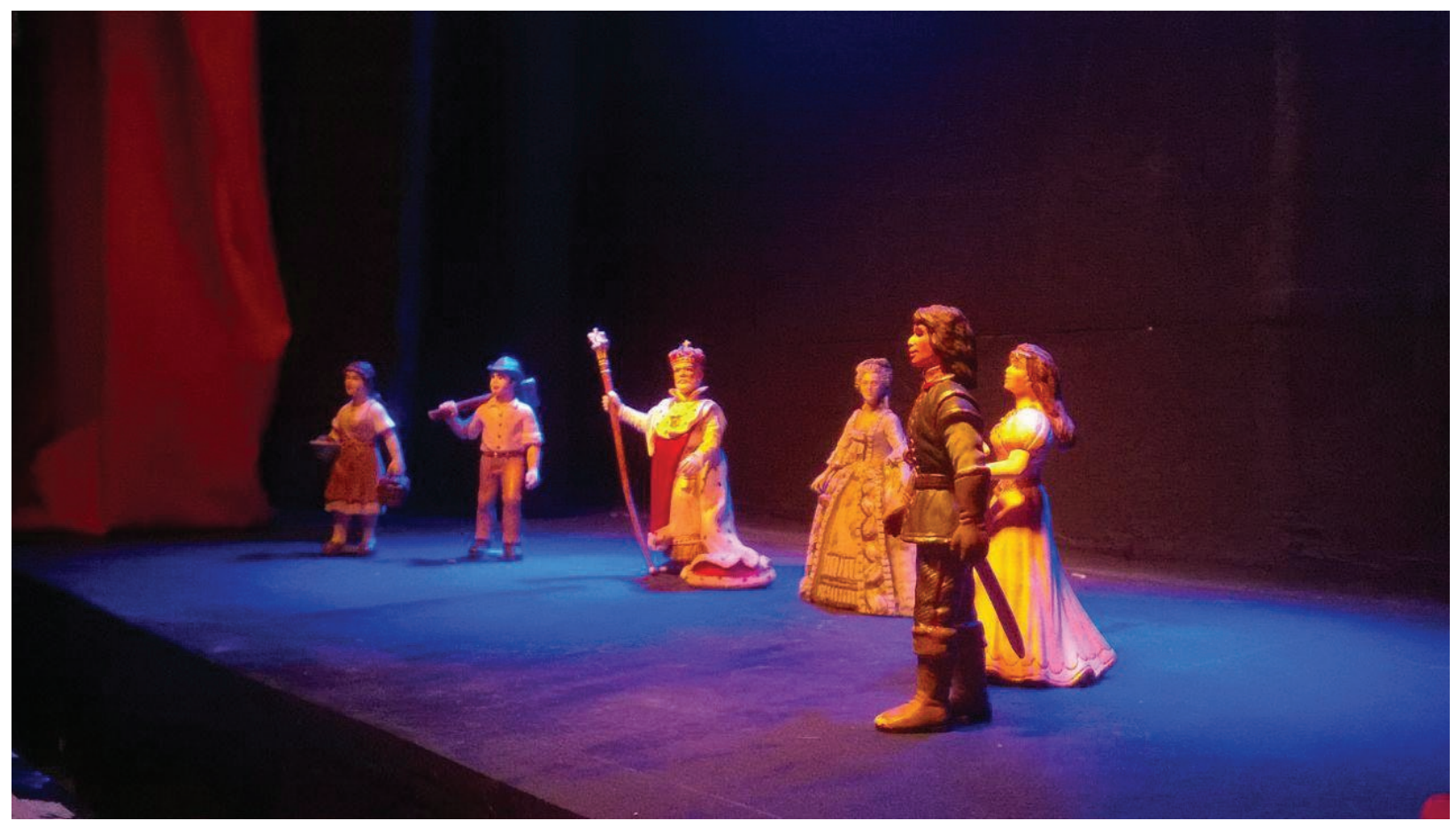

Figura 2 - Pelo áudio o/a jogador(a) é orientado a observar na maquete a interação entre contra luz azul/laterais amarelo sobre personagens e seus figurinos. Foto: Juciê Borges

Benjamin nos lembra assertivamente que "todo desempenho infantil se orienta não pela 'eternidade' dos produtos, mas sim pelo 'instante' do gesto. O teatro, enquanto arte efêmera, é infantil" (Benjamin, 1984, p.87). Jogar luzes sobre o palco da maquete propicia a exploração visual e operacional das cores e movimentos de luz que são feitos, num primeiro momento, seguindo um roteiro de áudio que descreve uma imagem a partir do acionamento de alguns dos botões numerados no painel operacional. O áudio vai guiando o espectador/operador ditando o número do botão ou botões a serem acionados para obter determinados efeitos de luz ou cor. O áudio descreve que elementos materiais da luz foram acionados para obtenção de cada efeito e solicita ao jogador que observe as composições visuais obtidas.

Em outros momentos a/o espectador épico pode manusear livremente os botões e experimentar composições diferentes, conforme seus gestos criados com a luz, sobre as superfícies dos corpos de objetos e espaços da maquete. Nesse processo pode usar uma música de sua predileção por exemplo, para dar apoio rítmico-temporal para seus 'gestos' iluminadores e operacionais com a luz. 


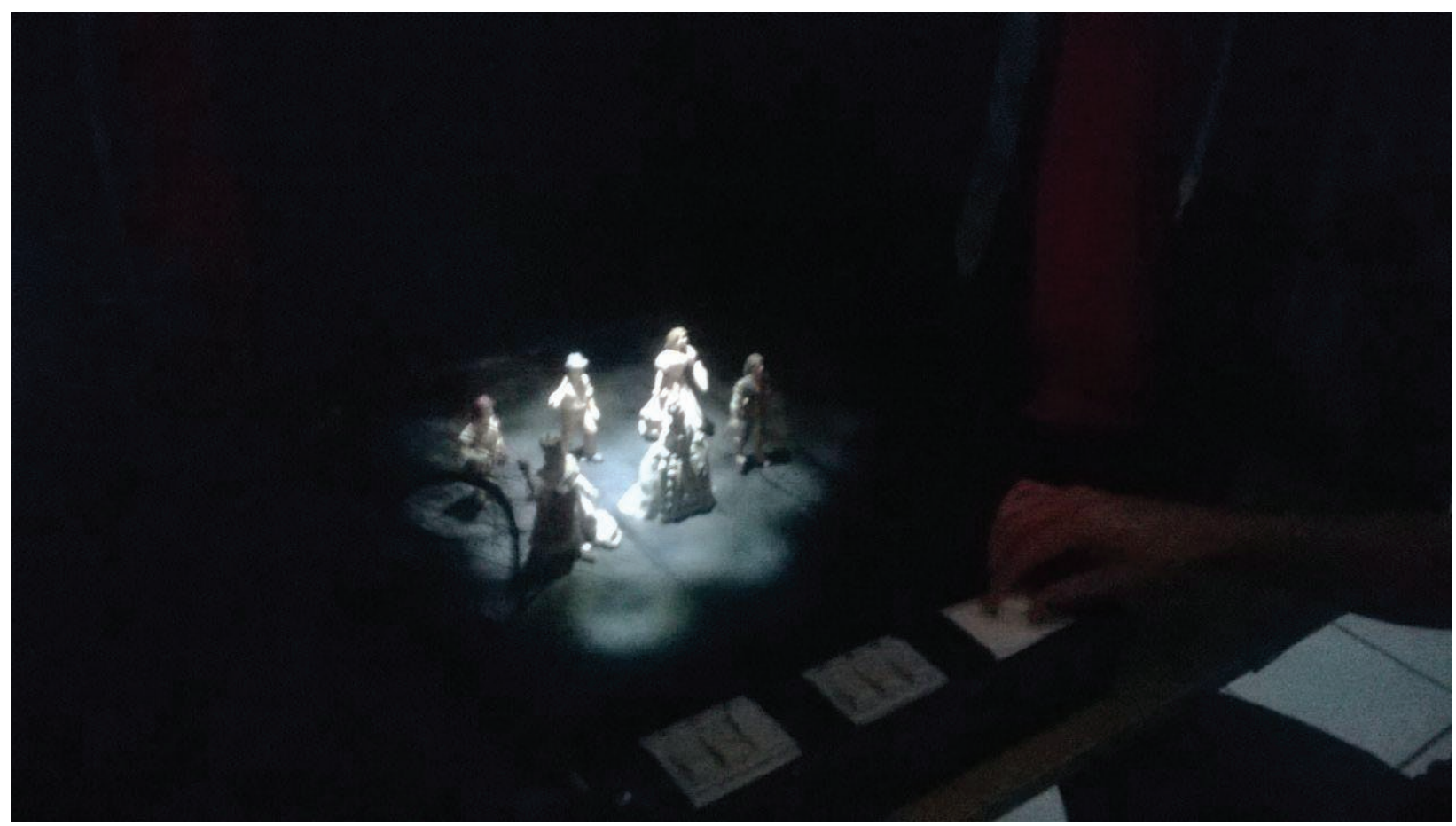

Figura 3 - Exercício com sombra e luz sobre personagens na maquete. Foto: Juciê Borges

Na primeira abordagem segue uma audiodescrição que proporciona a mediação dos jogos de luz que se pode executar como lições básicas na maquete. No roteiro desse áudio estão previstos os momentos de pausa, quando se pede ao espectador que observe as imagens criadas e registre suas impressões (figura 3). Em outras passagens se pede que se repita um movimento várias vezes, ou que se mude abruptamente de uma composição para outra, visando procurar semelhanças e diferenças nas imagens obtidas com recursos de cores e/ou efeitos combinados a partir das luzes disponíveis na maquete.

Dessa maneira a repetição outro traço do comportamento infantil que Benjamin aponta como característico do espírito de jogo e brincadeira, que é o prazer de fazer de novo uma vez mais. "A essência do brincar não é fazer como se, mas um fazer sempre de novo, a transformação da experiência mais comovente em hábito" (Benjamin, 1984, p.75).

A partir da experiência lúdica na caixa de brinquedo/palco pretende-se transmitir algumas lições básicas sobre iluminação cênica nesse tipo de espaço, por meio de visualizações concretizadas com materialidades luminosas agindo sobre o tempo/espaço do jogo operacional sobre o palco imaginário da maquete. Esta prática pedagógica desenvolvida nas aulas de cenografia e iluminação cênica do curso de Licenciatura em Teatro da UFRN, e aplicada no projeto PIBID - Programa de Bolsas de Iniciação à Docência, no núcleo Teatro da UFRN, é uma proposta para o manuseio do elemento teatral luz de forma a estimular a compreensão de seu potencial de manipulação das visualidades da cena, e por contextualizações em outros meios e espaços que usem luz artificial como instrumento tecnológico de atuação.

O conjunto didático da maquete/brinquedo propõe um espaço onde pode ser demonstrado visualmente alguns efeitos de iluminação cênica, onde o que chamamos luz, é manuseado pelos jogadores, e onde a mediação da audiodescrição instala 
por instantes uma a ser manuseada pelos sujeitos ativos nos jogos de luz sobre o espaço da maquete, e onde aos poucos vamos introduzindo modos de observação das imagens, lupas, geradas de forma lúdica e prazerosa. Essa lupa propõe observação mediada para essas imagens e impressões causadas pelos efeitos de luzes e que podem ser reverberadas em novos filtros geradores de conhecimentos científicos sobre luz, cor e seus papéis nas encenações.

Esse processo em três fases (luz, jogo e lupa) propicia experiências práticas elementares sobre iluminação cênica, mediadas pelo professor/formador no intuito de estabelecer alguns parâmetros teóricos para transformar a vivência empírica do jogo/ brinquedo em experiência que gera conhecimento. O objetivo oculto do jogo com os botões operacionais da maquete é instrumentalizar seu público com um olhar analítico e crítico para presença da luz na cena. Este 'brinquedo' didático propõe um manuseio continuado, de muitos momentos absortos experimentando várias formas de atuar com a luz sobre o espaço da maquete e seus elementos.

No quadro abaixo e nas fotos a seguir alguns exemplos das fases para o manuseio de luzes na maquete: 


\begin{tabular}{|c|c|c|c|}
\hline & LUZ & JOGO & LUPA \\
\hline $\begin{array}{l}\text { CORES LUZ } \\
\text { BRANCO } \\
\text { ÂMBAR }\end{array}$ & $\begin{array}{l}\text { Sistema RGB de } \\
\text { cores primárias em } \\
\text { luz; } \\
\text { Cores únicas bran- } \\
\text { co e âmbar. }\end{array}$ & $\begin{array}{l}\text { Operar diversas } \\
\text { misturas aditivas } \\
\text { das cores pri- } \\
\text { márias }\end{array}$ & $\begin{array}{l}\text { Observar as cores secun- } \\
\text { dárias geradas. Observar } \\
\text { as interações físicas das } \\
\text { cores em diversas situa- } \\
\text { ções (Figura 4) }\end{array}$ \\
\hline $\begin{array}{l}\text { ESPACIALIDADE } \\
\text { 2D e 3D }\end{array}$ & $\begin{array}{l}\text { Direcionamento e } \\
\text { angulação do feixe } \\
\text { de luz; Planos e } \\
\text { áreas. } \\
\text { (Figura 4) }\end{array}$ & $\begin{array}{l}\text { Manuseio de } \\
\text { imagens com } \\
\text { aproximação e } \\
\text { distanciamento; } \\
\text { Corpos e obje- } \\
\text { tos no espaço } \\
\text { recebem luz e } \\
\text { geram sombras } \\
\text { e imagens em } \\
\text { planos e dimen- } \\
\text { sões }\end{array}$ & $\begin{array}{l}\text { Como cada cor impacta } \\
\text { na construção visual? } \\
\text { Que luzes/que posição } \\
\text { favorece a 2D ou a 3D? } \\
\text { Como fica a espacialida- } \\
\text { de composta com som- } \\
\text { bra e penumbra? (Figura } \\
6 \text { e } 7\end{array}$ \\
\hline $\begin{array}{l}\text { COMPOSIÇÃO } \\
\text { VISUAL E/OU } \\
\text { ATMOSFERAS }\end{array}$ & $\begin{array}{l}\text { Luz e sombras, } \\
\text { intensidades; con- } \\
\text { trastes; aridez ou } \\
\text { aconchego }\end{array}$ & $\begin{array}{l}\text { Com o painel de } \\
\text { controle de bo- } \\
\text { tões da maque- } \\
\text { te criar efeitos } \\
\text { de luzes sobre o } \\
\text { palco. }\end{array}$ & $\begin{array}{l}\text { Efeitos dramáticos e ou- } \\
\text { tros (Figura 5) }\end{array}$ \\
\hline
\end{tabular}

Tabela dos conteúdos sobre luz cênica operacionalizados na maquete ${ }^{3}$

${ }^{3}$ As lições contidas nesta tabela podem ser extraídas de diversos livros já editados em português. Nas aulas para estudantes de teatro recomendamos o livro de Marcelo Santana presente nas referências deste trabalho. 


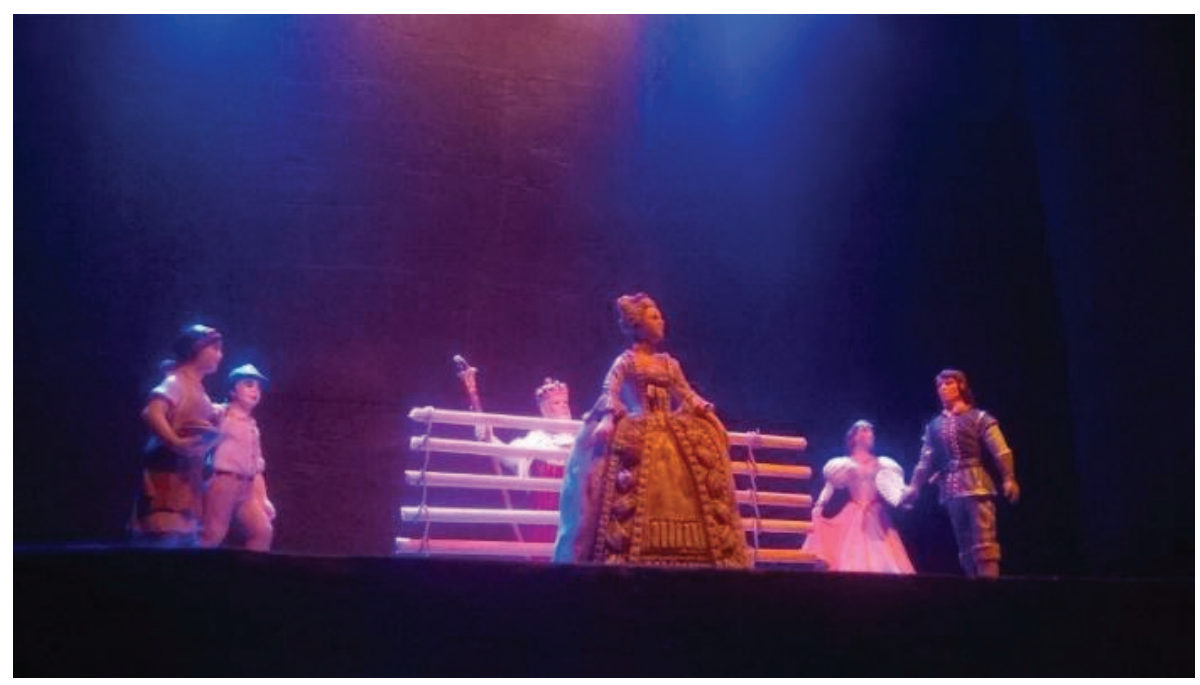

Figura 4 - Interações físicas cor luz e cor pigmento

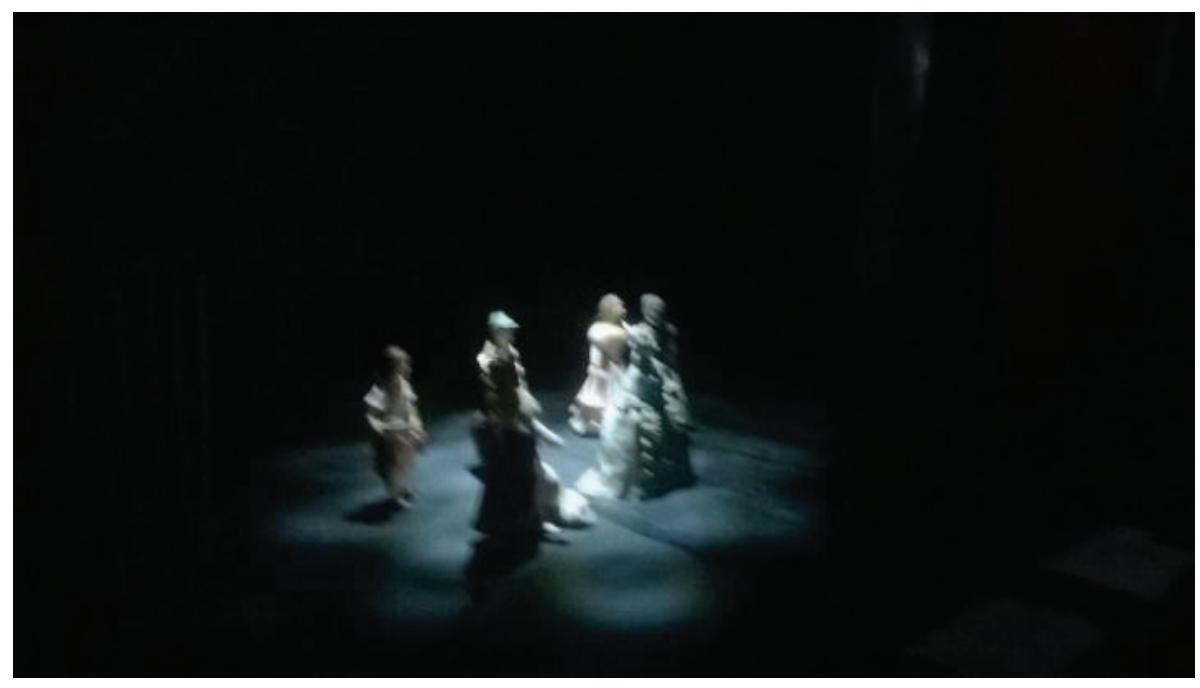

Figura 5 - Contrastes luz/sombra no corpo e espaço

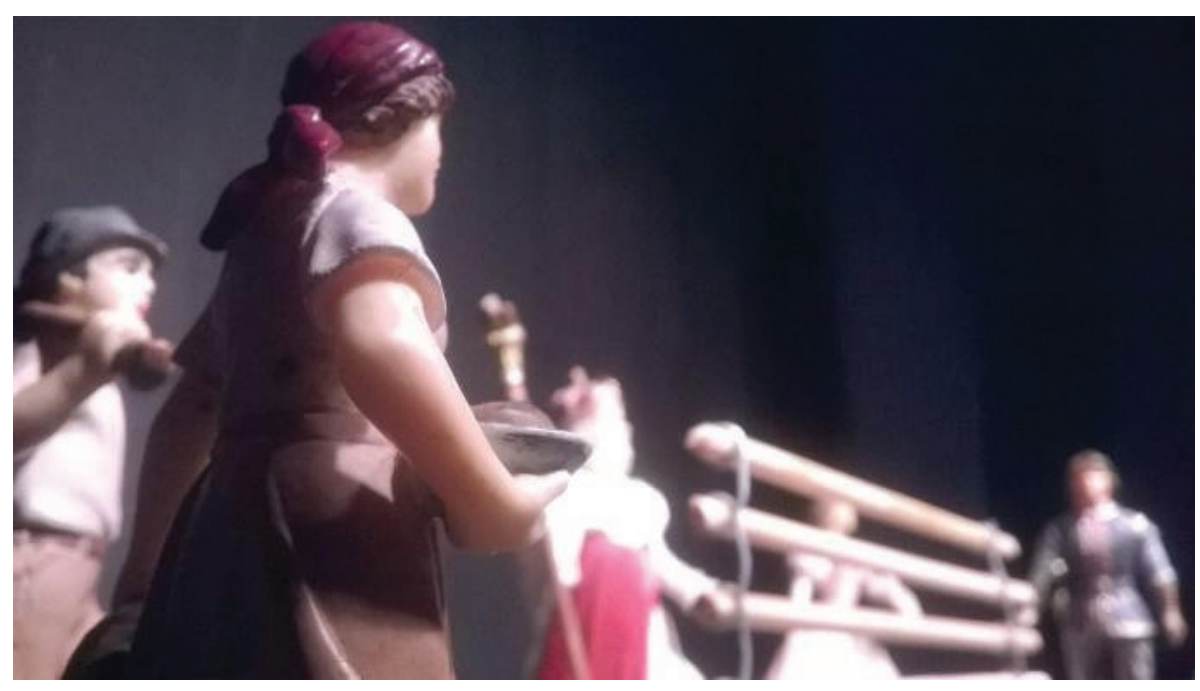

Figura 6 - A luz e a construção da 3D no palco 


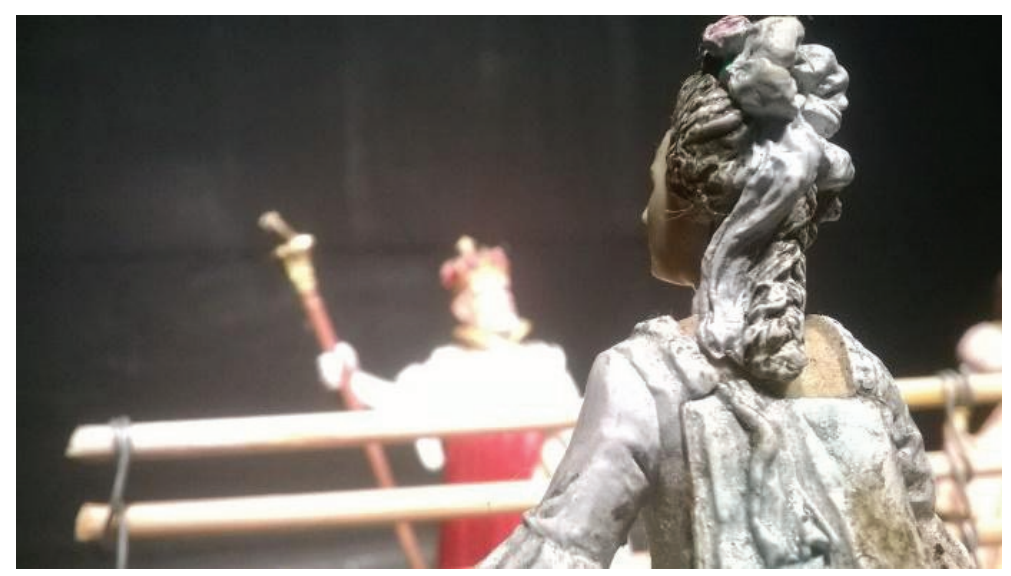

Figura 7 - A luz como reveladora de formas e cores Fotos: Juciê Borges

Dessa forma a vivência em diversos 'gestos operacionais' de efeitos de luz lançados sobre personagens e espaço, com as consequentes visualizações e observações das imagens nela geradas, podem se transformar em experiência quando apreciadas a partir de olhares treinados de forma lúdica e, posteriormente analíticos, nos momentos dialógicos da mediação estabelecida entre instrutor do jogo e espectador/ espectadora que operacionaliza luz na maquete.

Como destaca Flávio Desgranges o desnudamento da cena, revelando seus elementos constitutivos e construtores de teatralidades expressivas nos eventos e apresentações, faz parte da pedagogia para o espectador épico pois, "Brecht pretendia, justamente, que o espectador ganhasse intimidade com a linguagem teatral". (Desgranges, 2015, p.171). A maquete pode ser, por exemplo, um instrumento de introdução temática antes de uma visita à caixa cênica de um teatro profissional tradicional.

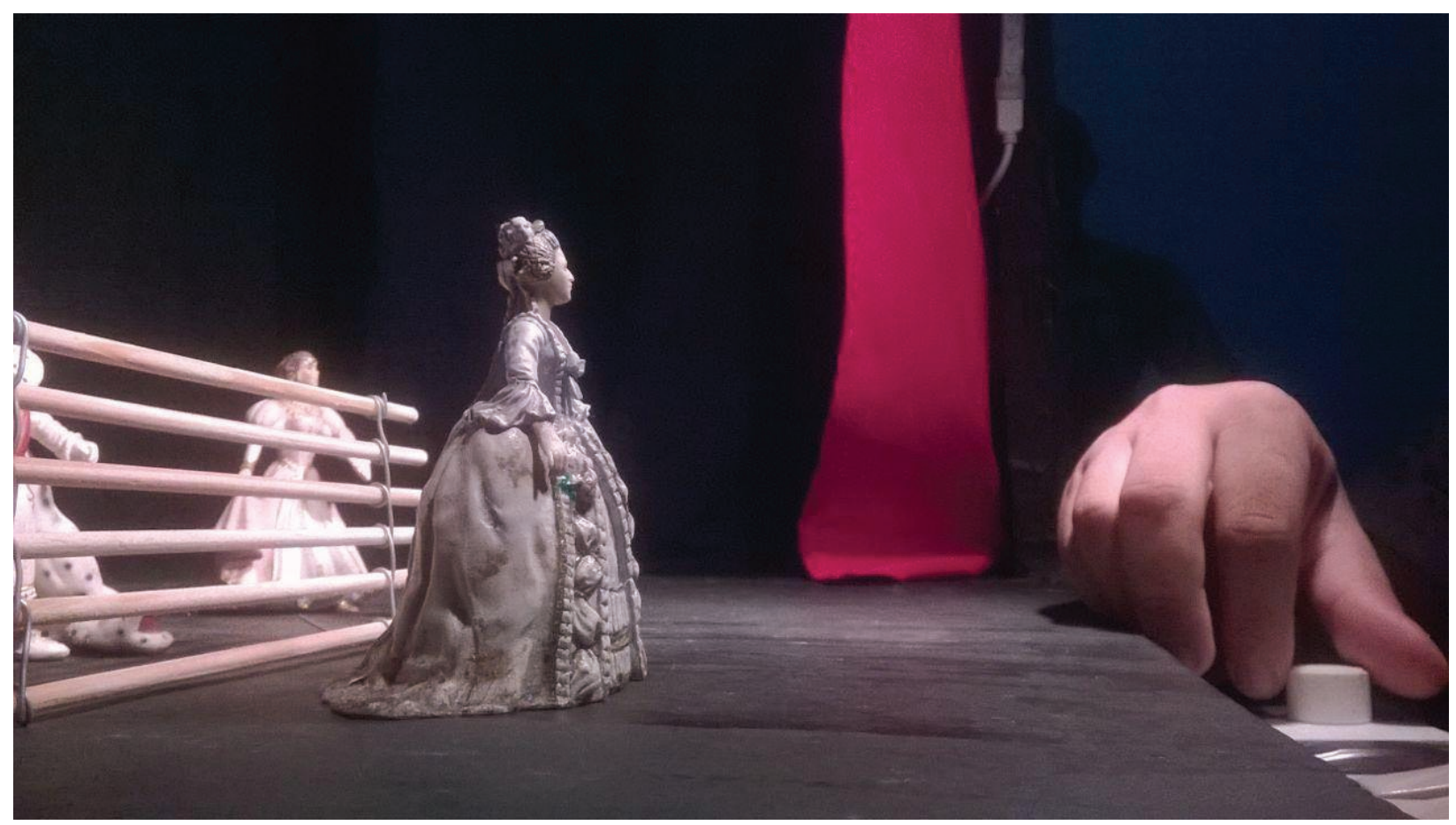

Figura 8 - Espectador/jogador acende luz sobre personagens no palco da maquete Foto: Juciê Borges 


\section{Brinquedo e Jogo - Quando a experiência mágica se transforma em ciência}

Nos textos sobre sua própria infância Walter Benjamin (1993) desenvolve preciosos registros de suas experiências como fruidor de jogos, brinquedos e livros infantis. A caixa de brinquedos é espaço de fantasias renovadas por imaginários sucessivos e intermitentes como um carrossel, e funciona para a criança como um 'canteiro de obras', na 'imagem do pensamento' do autor, sobre os impulsos lúdicos das crianças em direção a todos tipos de objetos que podem virar brinquedos. Num texto chamado Esconderijos, Benjamin nos traz memórias de sua primeira infância quando morava com a família na mansão de burgueses ricos, onde ele percorria com seu pequeno corpo os altos e distantes espaços da casa; onde vivia a imaginar toda sorte de demônios e seres mascarados à espreita nos recantos escondidos da casa e dos móveis pesados e escuros. O menino assombrado viaja pelos trajetos embaixo de mesas que só ele sabia visitar e enxergar em aventuras constantes. Mas tais aventuras são suspensas:

Uma vez por ano, porém, em lugares secretos, em órbitas vazias, em suas bocas hirtas, havia presentes; a experiência mágica virava ciência. Como seu eu fosse seu engenheiro, eu desencantava aquela casa sombria à procura de ovos de Páscoa. (Benjamin, 1993, p.91).

Nessa breve narrativa de memórias da sua própria infância o autor nos revela como se processa na prática a ideia de experiência significativa, na perspectiva benjaminiana, onde esta é uma experiência transformadora e deflagradora de memória, entendida como algo que passa a fazer parte da identidade da pessoa, e proporciona conexões conscientemente articuladas sobre temas, assuntos e suas derivações processadas pela razão investigadora. O processamento e construção de um olhar científico para onde, até então, só havia o pensamento mágico, aponta um dos caminhos dos movimentos de sentido para a palavra experiência.

Gagnebin (1993) nos explica a potencialidade da Experiência, em alemão Erfahrung, conceito desenvolvido dentro da obra de Benjamin em diversos textos da juventude e da maturidade, e que pode ser entendida como a possibilidade de transmissão de conhecimentos por meio de narrativas tradicionais, mas a autora nos adverte de que essa concepção não deve ser entendida apenas em sua "dimensão nostálgica e romântica" (Gagnebin, 1993 p. 10).

Transposta para o contexto de uma ação educativa com teatro, esse brinquedo/ maquete possibilita algo mais do que meras vivências sensoriais e cognitivas para apreciação da arte teatral, mas também pode proporcionar alguma experiência que possa fazer parte da memória constituinte do sujeito e de seu processo de construção de identidade cultural, na medida em que enxerga e interfere com a luz no mini palco ao elaborar seus próprios gestos luminosos sobre a maquete, ao mesmo tempo em que pode produzir narrativas com os elementos que dispõe nesse brinquedo, que reúne cor luz das lâmpadas e a cor pigmento dos objetos num espaço propício para 
pontos de construção e observação da atuação desses mini produtos cênicos.

Em relação aos poderes da iluminação de manipular as imagens impressas, filmadas e outras, podemos pensar um espectador épico quando ele/ela têm repertório de experiência e conhecimento para desvendar os sentidos construídos com desenhos de luz na cena, e dessa forma incorporar nomenclaturas, conceitos e instrumentos para 'ler' as manifestações da iluminação como poéticas e/ou estéticas na cena e, por experiência adquirida, transferir essas referências para análise de suas estéticas em outros âmbitos de suas manifestações.

A proposta pedagógica desta maquete busca trilhar esse viés da experiência buscando propiciar essa memória que permanece como substância e conhecimento, descortinando elementos de leituras para o mundo e a realidade da iluminação como presença na cena. Aquela vivência sensorial definida como mágica quando cheia de cores, ou assombrosa quando a cena mergulha na penumbra ou escuridão, pode se tornar ciência nas mãos de um brinquedo/maquete de produção de efeitos de iluminação cênica, que buscam aprofundar a experiência cognitiva com luz por meio do jogo.

\section{Considerações finais}

Desde o século passado as possibilidades de intervenções luminosas sobre a cena se ampliaram como suporte da criação de códigos significantes no espaço ficcional e poético do teatro por meio de equipamentos providos de lentes e manipulados por intensidades elétricas. Na atualidade, após o advento das tecnologias digitais e robóticas novos equipamentos ampliaram exponencialmente as possibilidades de produção de desenhos luminosos nos espaços espetaculares, aumentando a manipulação sensorial e perceptiva que a cena lança em direção aos seus espectadores por intermédio da iluminação.

Esse elemento material pulsante e vibracional atua nas várias direções da potência da luz para gerar imagens, sensações e codificação espacial e outras tantas possibilidades e nesses caminhos elabora e ritualiza o fascínio das artes do espetáculo pelos efeitos visuais. Nesse contexto o ensino dos fundamentos técnicos da iluminação cênica passa a fazer parte do repertório de conhecimentos para apreciação crítica do espectador épico proposto por Desgranges.

Benjamin nos convida a pensar a arte por meio de 'constelações' de pontos de enfoque, que podem ser ativados para traçar uma formulação singular e histórica a cada novo olhar sobre seus objetos, que recebem configurações recriadas por meio do processo crítico. Seguindo suas 'constelações de pensamentos' sobre técnica, magia, aura e mercadoria presentes em obras de arte podemos observar, por exemplo, como o senso comum sobre a 'magia' trazida pela presença da luz, incrementa o fetiche tecnológico que domina parte das práticas de projetos na área, e que reforçam apenas os pontos de vista de um dos lados do papel da iluminação cênica em espetáculos, nos quais os espectadores videntes podem ser bombardeados pela profusão frenética de luzes em movimento, em certos contextos que se propõem a somente isto como produto estético. 
Em contraposição acredito que olhar a luz para o espetáculo pelo filtro artesanal dessa maquete teatral proporciona uma experiência diferenciada e instaura um senso de observação de suas manifestações estéticas a partir do manuseio de sua materialidade no palco em miniatura, que pode ser o início da construção de olhares críticos sobre as manifestações da iluminação cênica em outros contextos de produção profissional, como, por exemplo, na área do show business, e dessa forma, pode contribuir para fomentar diálogos analíticos de apreciação sobre os papéis e as consequências dos fenômenos poéticos e estéticos da luz no universo do espetáculo, um tema que perpassa a experiência cultural de crianças e jovens em diversos contextos.

\section{Referências}

BENJAMIN, Walter. Reflexões: A criança o brinquedo a educação. Trad. Marcus Mazzari. São Paulo: Summus, 1884.

BENJAMIN, Walter. Rua de mão única. Trad. Rubens Rodrigues Torres Filho, São Paulo: Brasiliense, 1993.

BRECHT, Bertolt. Estudos sobre Teatro. Trad. Fiama P. Brandão. Rio de Janeiro: Nova Fronteira, 1978.

DESGRANGES, Flávio. A pedagogia do espectador. 3ed. São Paulo: Hucitec, 2015.

GAGNEBIN, Jeanne Marie. Walter Benjamin ou a história aberta. In: Magia e Técnica, Arte e Política. (Prefácio). São Paulo: Ed. Brasiliense, 1993.

KOUDELA, Ingrid; ALMEIDA JR., José S. Léxico de Pedagogia do Teatro. São Paulo: Perspectiva, 2015.

SANTANA, Marcelo A. Haja luz - Manual de iluminação cênica. Brasília: Senac, 2016.

Recebido em: 04/11/2019

Aprovado em: 16/02/2020 